Supporting Information 


\title{
Mechanism Study of Unsaturated Tripropargyl Phosphate as an Efficient Electrolyte Additive Forming Multifunctional Interphases in Lithium Ion and Lithium Metal Batteries
}

\author{
Yunxian Qian ${ }^{a, b, c, 1}$, Yuanyuan Kang ${ }^{a, b, c, 1}$, Shiguang $\mathrm{Hu}^{a, b, c}$, Qiao $\mathrm{Shi}^{b}$, Qun $\mathrm{Chen}^{b}$, \\ Xiwu Tang ${ }^{b}$, Yinglin $\mathrm{Xiao}^{a}$, Huajun Zhao ${ }^{a}$, Guangfu Luo ${ }^{a, *}, \mathrm{Kang} \mathrm{Xu}^{d, *}$, Yonghong \\ $\operatorname{Deng}^{a, *}$
}

${ }^{a}$ Department of Materials Science and Engineering, Southern University of Science and Technology (SUSTech), Shenzhen 518055, China.

${ }^{b}$ Shenzhen CAPCHEM Technology Co. Ltd., Shabo Tongfuyu Industry Zone, Pingshan District, Shenzhen, 518118, China.

${ }^{c}$ The Key Laboratory of Fuel Cell for Guangdong Province, School of Chemistry and Chemical Engineering, South China University of Technology, Guangzhou, 510640, China;

${ }^{d}$ Electrochemistry Branch, US Army Research Laboratory, Adelphi, MD 20783, USA

${ }^{1}$ These authors (Y. Qian and Y. Kang) contributed equally to this paper.

*Corresponding author: luogf@sustech.edu.cn (G. Luo), conrad.k.xu.civ@mail.mil (K.Xu), dengyh@sustech.edu.cn (Y. Deng) 
(a)

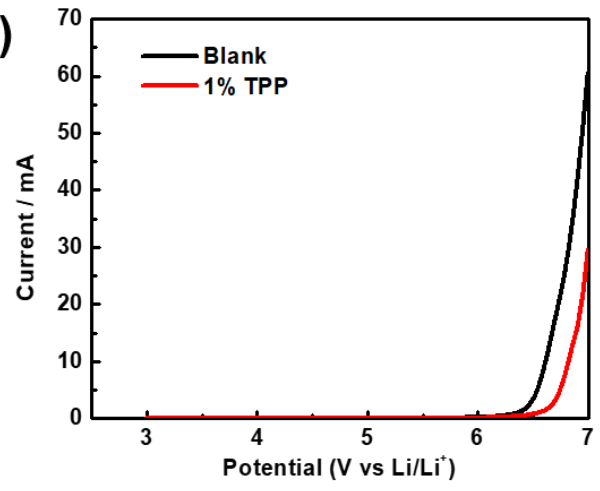

(c)

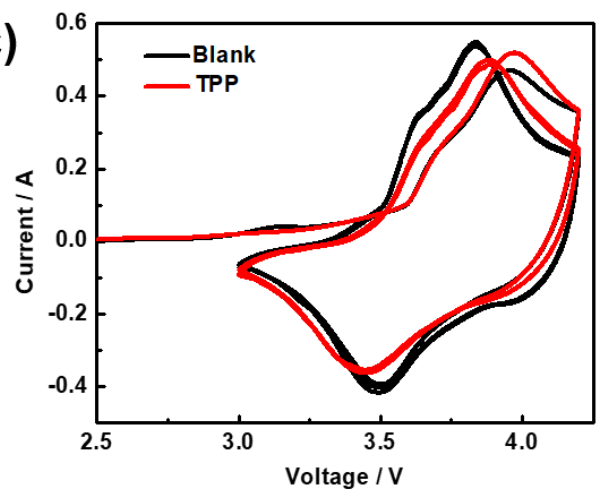

(b)

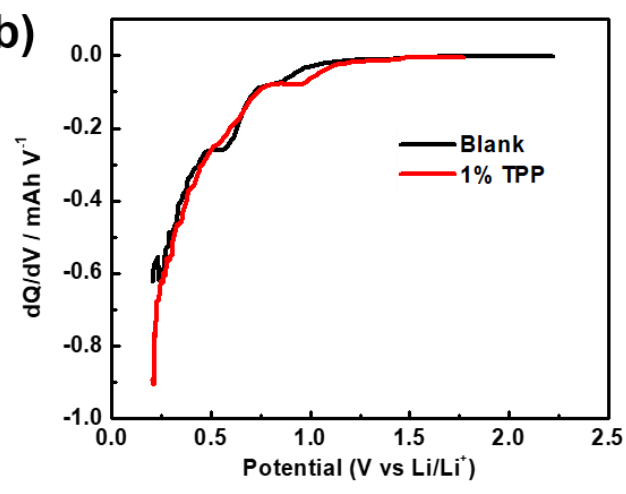

(d)

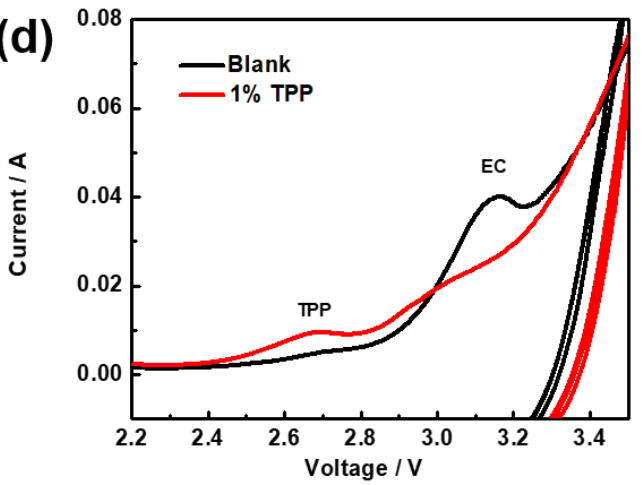

Figure S1. (a) The linear sweep voltammetry curve with with $\mathrm{Pt} / \mathrm{Li} / \mathrm{Li}$ as the working electrode (WE)/reference electrode (RE)/counter electrode (CE), (b) the dQ/dV curve with $\mathrm{AG} / \mathrm{Li}$ metal as $\mathrm{WE} / \mathrm{CE}$, (c) the original cyclic voltammetry curves and (d) the enlarged curves of the NMC532/AG pouchbag full cell with Baseline and TPP electrolyte systems. 
(a)

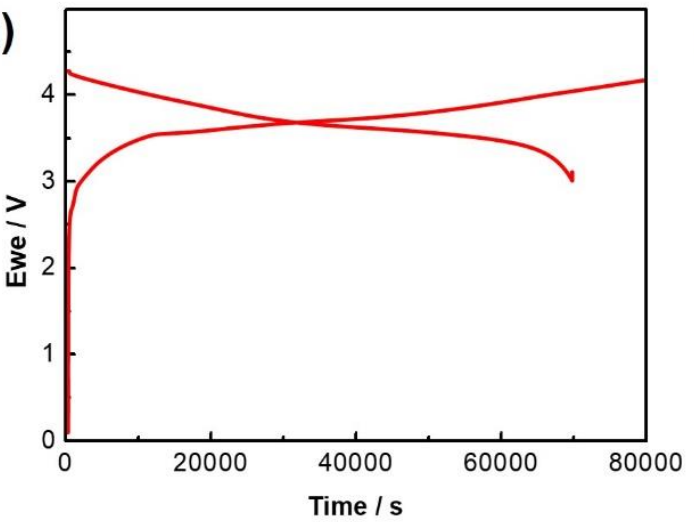

(b)

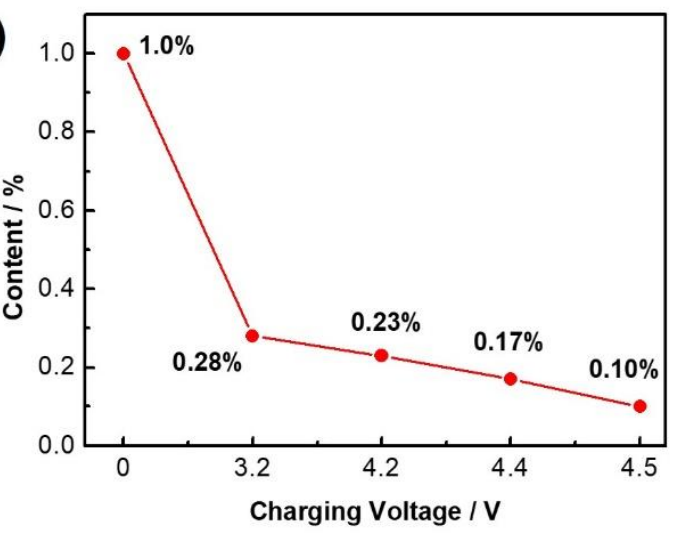

Figure S2. (a) The individual potentials of the NMC532 cathode and the AG anode with the increase of the full cell voltage measured via a T-cell setup, and (b) the consumption amount of TPP verified via the GC measurements.

With the help of the T-cell setup, the potential of both the NMC532 cathode and the AG anode can be determined during the full-cell charge-discharge process, as shown in Figure S2a. When the full cell is charged to $3.20 \mathrm{~V}$, the potential of the AG anode is $0.52 \mathrm{~V} \mathrm{vs} . \mathrm{Li}^{+}$(lower than the reduction potential of EC), while that of the cathode is $3.72 \mathrm{~V}$ vs. $\mathrm{Li}^{+}$. Hence, the consumption of TPP from $0-3.2 \mathrm{~V}$ is mainly decomposed on the anode side, while the consumption between $3.2-4.5 \mathrm{~V}$ is believed to be consumed mostly on the cathode side. With the help of GC, the consumption of TPP on the anode and the cathode is detected to be $72 \%$ and $28 \%$, respectively (Figure S2b). Hence, despite the high oxidation stability of TPP in the Pt/Li cells, it can participate in both the cathode $\&$ anode film-forming process of the NMC532/AG cell. 


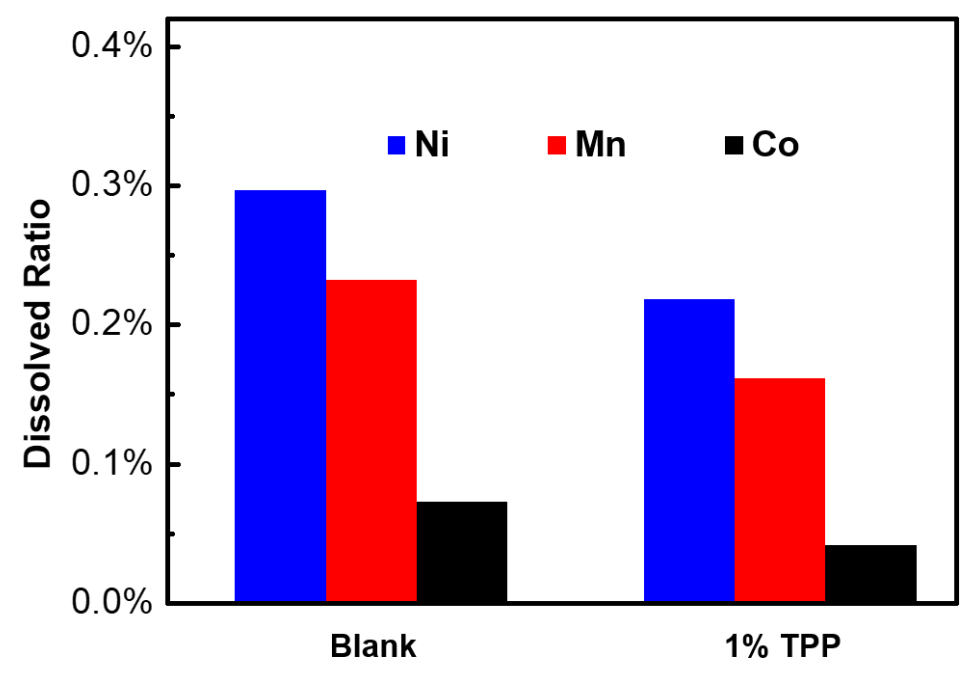

Figure S3. The metal ( $\mathrm{Mn}, \mathrm{Co}$ and $\mathrm{Ni}$ ) dissolution amounts for the Baseline and the TPP systems after the formation process, calculated based on the ICP-OES results.

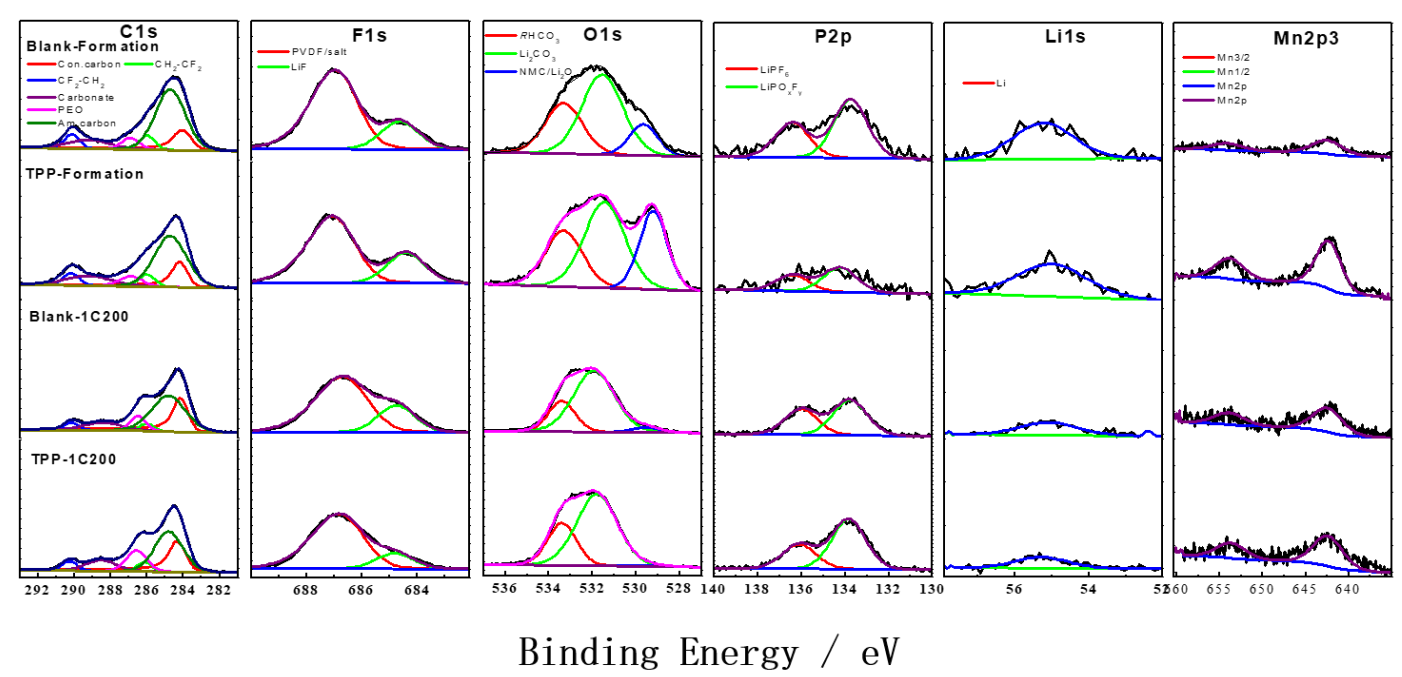

Figure S4. The C 1s, F 1s, O 1s, P 2p, Li 1s and Mn 2p3 spectra of NMC532 electrodes after the formation procedure and 200 cycles. 


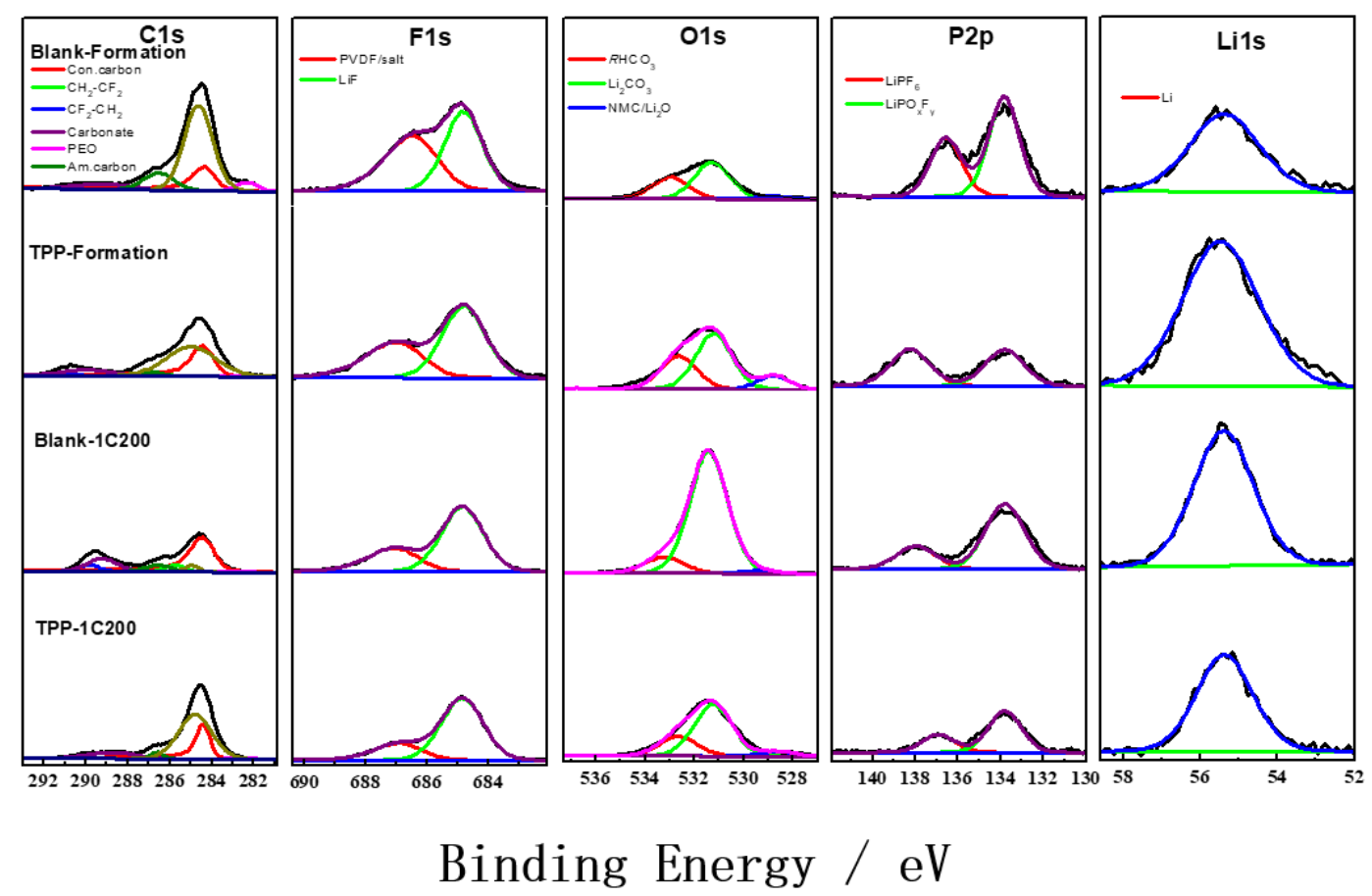

Figure S5. The C 1s, F 1s, O 1s, P 2p, Li 1s spectra of AG electrodes after the formation procedure and 200 cycles. 

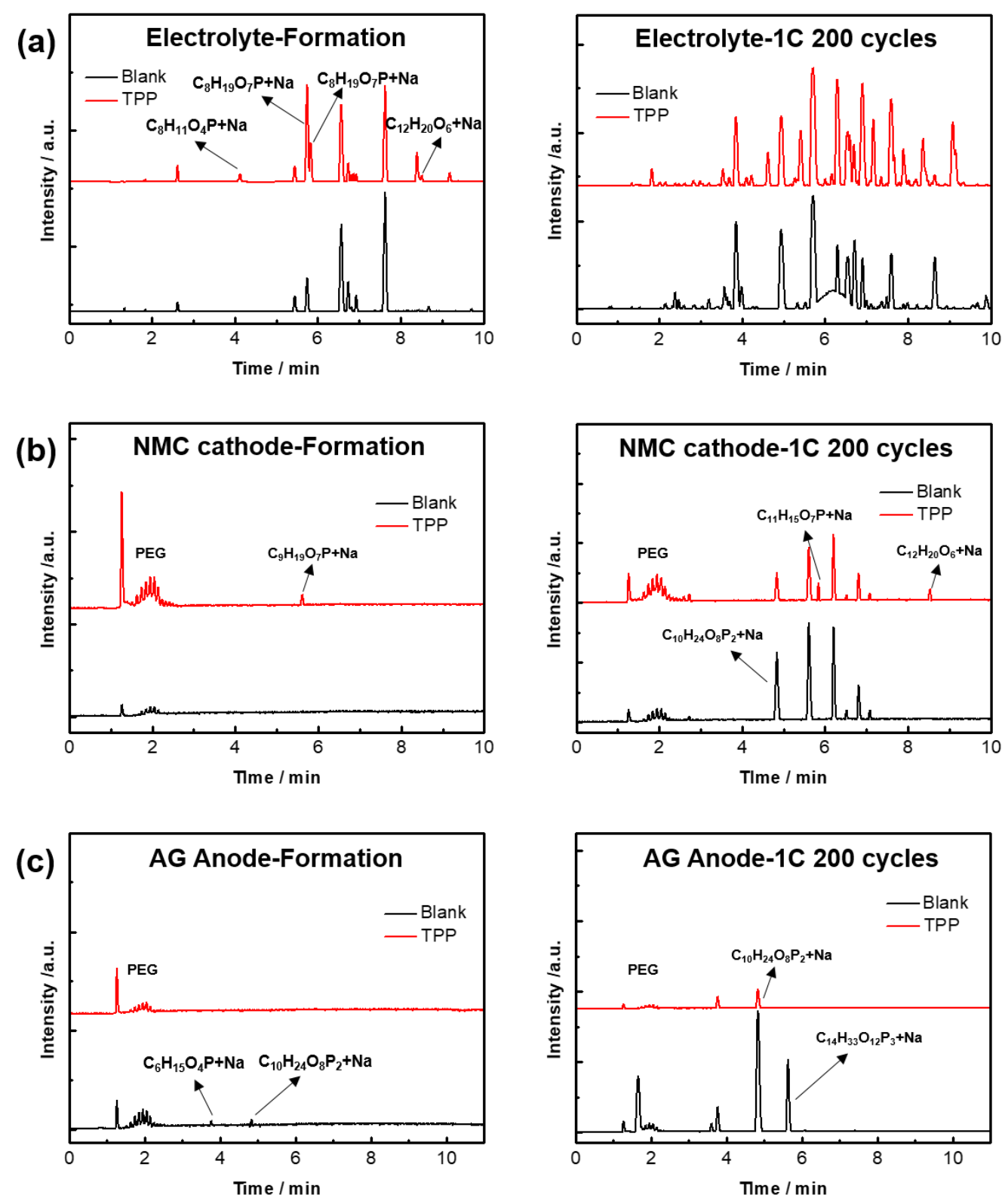

Figure S6. LC-MS chromatograms collected from (a) the electrolytes after formation (left) and 200 cycles (right), (b) CA after formation (left) and 200 cycles (right) and (c) AN after formation (left) and 200 cycles (right). The electrodes and electrolytes were extracted from the NMC532/AG cells and soaked in ACN for LC-MS detection. The formed CEI and CEI were broken away from the electrode surfaces under ultrasonic agitation. 
Table S1. The cathode and anode potentials of the NMC532/AG in the T-cell.

\begin{tabular}{|c|c|c|}
\hline $\mathrm{E}_{\text {cell }} / \mathrm{V}$ & $\mathrm{E}_{\text {we }} / \mathrm{V}$ & $\mathrm{E}_{\mathrm{ce}} / \mathrm{V}$ \\
\hline 0.085 & 3.21 & 3.13 \\
\hline 3.00 & 3.72 & 0.72 \\
\hline 3.20 & 3.73 & 0.53 \\
\hline 4.20 & 4.19 & 0 \\
\hline 4.40 & 4.39 & 0 \\
\hline 4.50 & 4.49 & 0 \\
\hline
\end{tabular}

Table S2. Computational binding energy between $\mathrm{Mn}^{2+}, \mathrm{Co}^{3+}, \mathrm{Ni}^{2+}$ and TPP, EC, DEC.

\begin{tabular}{cccc}
\hline & $\mathrm{Ni}^{2+} / \mathrm{eV}$ & $\mathrm{Mn}^{2+} / \mathrm{eV}$ & $\mathrm{Co}^{3+} / \mathrm{eV}$ \\
\hline TPP & -10.02 & -8.07 & -27.39 \\
EC & -6.82 & -5.88 & -20.05 \\
DEC & -6.99 & -5.79 & -21.94 \\
\hline
\end{tabular}


Table S3. LC-QTof-MS results collected from AG electrodes after formation and 200 cycles

\begin{tabular}{|c|c|c|c|c|c|}
\hline & & $\begin{array}{c}\text { Baseline- } \\
\text { formation }\end{array}$ & TPP-formation & $\begin{array}{c}\text { Baseline - } \\
\text { 200cycles }\end{array}$ & TPP-200cycles \\
\hline $\mathrm{T} / \mathrm{min}$ & $\mathrm{M} / \mathrm{Z}$ & Compound & Compound & Compound & Compound \\
\hline $\begin{array}{c}1.26- \\
2.49\end{array}$ & 305.1578 & PEG & PEG & PEG & PEG \\
\hline 1.65 & 141.0314 & & & $\mathrm{C}_{3} \mathrm{H}_{9} \mathrm{O}_{4} \mathrm{P}+\mathrm{H}^{+}$ & \\
\hline 3.6 & 343.0687 & & & $\mathrm{C}_{9} \mathrm{H}_{22} \mathrm{O}_{8} \mathrm{P}_{2}+\mathrm{Na}$ & \\
\hline 3.76 & 205.0617 & $\mathrm{C}_{6} \mathrm{H}_{15} \mathrm{O}_{4} \mathrm{P}+\mathrm{Na}$ & & $\mathrm{C}_{6} \mathrm{H}_{15} \mathrm{O}_{4} \mathrm{P}+\mathrm{Na}$ & $\mathrm{C}_{6} \mathrm{H}_{15} \mathrm{O}_{4} \mathrm{P}+\mathrm{Na}$ \\
\hline 4.83 & 357.0858 & $\mathrm{C}_{10} \mathrm{H}_{24} \mathrm{O}_{8} \mathrm{P}_{2}+\mathrm{Na}$ & & $\mathrm{C}_{10} \mathrm{H}_{24} \mathrm{O}_{8} \mathrm{P}_{2}+\mathrm{Na}$ & $\mathrm{C}_{10} \mathrm{H}_{24} \mathrm{O}_{8} \mathrm{P}_{2}+\mathrm{Na}$ \\
\hline 5.63 & 509.1079 & & & $\mathrm{C}_{14} \mathrm{H}_{33} \mathrm{O}_{12} \mathrm{P}_{3}+\mathrm{Na}$ & \\
\hline
\end{tabular}


Table S4. LC-QTof-MS results collected from NMC532 electrodes after formation and 200 cycles

\begin{tabular}{|c|c|c|c|c|c|}
\hline & & $\begin{array}{l}\text { Baseline - } \\
\text { formation }\end{array}$ & TPP -formation & $\begin{array}{l}\text { Baseline - } \\
\text { 200cycles }\end{array}$ & TPP-200cycles \\
\hline $\mathrm{T} / \mathrm{min}$ & $\mathrm{M} / \mathrm{Z}$ & Formula & Formula & Formula & Formula \\
\hline $\begin{array}{l}1.26- \\
2.49\end{array}$ & 305.1578 & PEG & PEG & PEG & PEG \\
\hline 2.72 & 309.0714 & & & $\mathrm{C}_{9} \mathrm{H}_{19} \mathrm{O}_{8} \mathrm{P}+\mathrm{Na}$ & $\mathrm{C}_{9} \mathrm{H}_{19} \mathrm{O}_{8} \mathrm{P}+\mathrm{Na}$ \\
\hline 4.83 & 357.0845 & & & $\mathrm{C}_{10} \mathrm{H}_{24} \mathrm{O}_{8} \mathrm{P}_{2}+\mathrm{Na}$ & $\mathrm{C}_{10} \mathrm{H}_{24} \mathrm{O}_{8} \mathrm{P}_{2}+\mathrm{Na}$ \\
\hline 5.62 & 293.0774 & $\mathrm{C}_{9} \mathrm{H}_{19} \mathrm{O}_{7} \mathrm{P}+\mathrm{Na}$ & $\mathrm{C}_{9} \mathrm{H}_{19} \mathrm{O}_{7} \mathrm{P}+\mathrm{Na}$ & $\mathrm{C}_{9} \mathrm{H}_{19} \mathrm{O}_{7} \mathrm{P}+\mathrm{Na}$ & $\mathrm{C}_{9} \mathrm{H}_{19} \mathrm{O}_{7} \mathrm{P}+\mathrm{Na}$ \\
\hline 5.63 & 509.1079 & & & $\mathrm{C}_{14} \mathrm{H}_{33} \mathrm{O}_{12} \mathrm{P}_{3}+\mathrm{Na}$ & $\mathrm{C}_{14} \mathrm{H}_{33} \mathrm{O}_{12} \mathrm{P}_{3}+\mathrm{Na}$ \\
\hline 5.84 & 313.0455 & & & & $\mathrm{C}_{11} \mathrm{H}_{15} \mathrm{O}_{7} \mathrm{P}+\mathrm{Na}$ \\
\hline 6.21 & 445.1003 & & & $\mathrm{C}_{13} \mathrm{H}_{28} \mathrm{O}_{11} \mathrm{P}_{2}+\mathrm{Na}$ & $\mathrm{C}_{13} \mathrm{H}_{28} \mathrm{O}_{11} \mathrm{P}_{2}+\mathrm{Na}$ \\
\hline 6.52 & 597.124 & & & $\mathrm{C}_{17} \mathrm{H}_{37} \mathrm{O}_{15} \mathrm{P}_{3}+\mathrm{Na}$ & $\mathrm{C}_{17} \mathrm{H}_{37} \mathrm{O}_{15} \mathrm{P}_{3}+\mathrm{Na}$ \\
\hline 6.81 & 381.0931 & & & $\mathrm{C}_{12} \mathrm{H}_{23} \mathrm{O}_{10} \mathrm{P}+\mathrm{Na}$ & $\mathrm{C}_{12} \mathrm{H}_{23} \mathrm{O}_{10} \mathrm{P}+\mathrm{Na}$ \\
\hline 7.08 & 533.1179 & & & $\mathrm{C}_{16} \mathrm{H}_{32} \mathrm{O}_{14} \mathrm{P}_{2}+\mathrm{Na}$ & $\mathrm{C}_{16} \mathrm{H}_{32} \mathrm{O}_{14} \mathrm{P}_{2}+\mathrm{Na}$ \\
\hline 8.51 & 283.1153 & & & & $\mathrm{C}_{12} \mathrm{H}_{20} \mathrm{O}_{6}+\mathrm{Na}$ \\
\hline
\end{tabular}

